\title{
Nutrient Changes and in Vitro Digestibility in Generative Stage of M10-BMR Sorghum Mutant Lines
}

\author{
R. Sriagtula ${ }^{a}$, P. D. M. H. Karti ${ }^{b, *}$, L. Abdullah ${ }^{b}$, Supriyanto ${ }^{c}$, \& D. A. Astuti ${ }^{b}$ \\ aDepartment of Nutrition and Feed Science, Faculty of Animal Science, Andalas University \\ Limau Manis, Padang, Sumatera Barat, Indonesia \\ ${ }^{b}$ Department of Nutrition and Feed Technology, Faculty of Animal Science, Bogor Agricultural University \\ 'Department of Silviculture, Faculty of Forestry, Bogor Agricultural University \\ Jalan Agatis, Kampus IPB Darmaga Bogor 16680, Indonesia \\ (Received 19-04-2017; Reviewed 08-06-2017; Accepted 18-07-2017)
}

\begin{abstract}
The objective of this research was to investigate the influences of generative stage on crude protein, crude fiber, ash, and crude fat contents as well as in-vitro dry matter and organic matter digestibilities of M-10 BMR sorghum mutant lines. This research was arranged into a randomized block design with 2 factors. The first factor was M-10 BMR sorghum mutant lines (Patir 3.1, Patir 3.2 and Patir 3.7) and the second factor was generative stages (flowering, soft dough and hard dough phase). The observed variables were proximate contents of stem, leaves and panicle of sorghum plant and in-vitro digestibility of whole plant. The results showed that leaves crude protein (CP) was more influenced by M-10 BMR sorghum mutant lines. Stems and panicles CP were influenced by the interaction between M-10 BMR sorghum mutant lines and generative stages. Further generative stage reduced stems $C P$ but increased panicles CP. Crude fiber (CF), ash, and ether extract (EE) in leaves were not influenced by generative stages. Stems CF was influenced by M-10 BMR sorghum mutant lines and generative stages, while stems EE was more influenced by generative stages. Stems ash content was influenced by the interaction between M-10 BMR sorghum mutant lines and generative stages while panicles ash content was more influenced by generative stages. M-10 BMR sorghum mutant lines and hard dough phase increased in-vitro dry matter and organic matter digestibilities. Based on those findings, it can be concluded that the increased maturity reduces $\mathrm{CP}$ and CF contents so it increases in-vitro digestibilities.
\end{abstract}

Keywords: brown midrib sorghum, in vitro digestibility, generative stage, sorghum mutant lines

\section{ABSTRAK}

Penelitian ini bertujuan untuk menganalisis pengaruh fase generatif pada kandungan protein kasar, serat kasar, abu, dan lemak kasar, serta kecernaan bahan kering dan bahan organik galur sorgum mutan BMR secara in vitro. Penelitian ini menggunakan rancangan acak kelompok pola faktorial dengan 2 faktor. Faktor pertama adalah galur sorgum BMR (Patir 3.1, Patir 3.2, dan Patir 3.7) dan faktor kedua adalah fase generatif (berbunga, soft dough, dan hard dough). Peubah yang diamati adalah kandungan proksimat batang, daun dan malai tanaman sorgum, serta kecernaan bahan kering dan bahan organik tebon sorgum. Hasil penelitian menunjukkan bahwa kandungan protein kasar pada daun dipengaruhi oleh galur sorgum mutan BMR M-10 $(\mathrm{P}<0,01)$. Kandungan protein kasar pada batang dan malai dipengaruhi oleh interaksi antara galur sorgum mutan M-10 dan fase generatif. Fase generatif lanjut menurunkan kandungan protein kasar pada batang, namun meningkatkan kandungan protein kasar pada malai. Kandungan serat kasar, abu dan lemak kasar pada daun tidak dipengaruhi oleh fase generatif, sedangkan kandungan serat kasar pada batang dipengaruhi oleh galur sorgum mutan BMR M-10 dan fase generatif. Kandungan lemak kasar pada batang dipengaruhi oleh fase generatif. Kandungan abu batang dipengaruhi oleh interaksi galur sorgum BMR M-10 dan fase generatif, sedangkan kandungan abu malai dipengaruhi oleh fase generatif. Galur sorgum BMR M-10 dan fase hard dough meningkatkan kecernaan bahan kering dan bahan organik secara in vitro. Kesimpulan penelitian adalah semakin tua umur tanaman maka semakin menurun kandungan PK dan SK, serta meningkatnya kecernaan secara in vitro.

Kata kunci: fase generatif, galur sorgum mutan, kecernaan, sorgum mutan 


\section{INTRODUCTION}

In general, forage is the main feed for ruminants with a daily consumption rate reaches $70 \%$ of the total ration. Besides of this huge amount, forage also plays a role as the main nutrition source for ruminants, therefore its availability is absolutely necessary. Forages should be maintained in ruminant diets because the production costs for forages are lower than for concentrate and more environmentally friendly, so it is more suitable for the development of sustainable livestock industry. Forage in diets helps maintain rumen function, reduces the risk of acidosis, and improves intake (Sari et al., 2015).

The development of sustainable forage is a challenge in running livestock business. The classical problem in the supply of forage in Indonesia is the lack of fertile land and low production in the dry season. To overcome those conditions, forage with high biomass production and more adaptive to marginal land such as sorghum is needed to be developed. Sorghum (Sorghum bicolor) is one of important crops and ranks at the fifth world's widest spread after wheat, rice, maize, and barley (Dahir et al., 2015). Sorghum is one of cereal crops consisting of forage and grains which potential to be used for fodder. Sorghum is also used to substitute maize (Zea mays) which is very potential to be cultivated in Indonesia. Sorghum has a good adaptation, tolerant to drought, and relatively produces higher biomass in less suitable climate and soil condition (Abdelhadi \& Tricarico, 2009).

However, forage is limited in supplying energy demand of ruminant due to the low digestibility and high content of cell wall. The lignin content of the maize plant is less than that of forage sorghums, so it also limits the consumption of sorghum by ruminants (Dann et al., 2008). This condition is caused by the reality that the sorghum used as forage is conventional varieties that are not designed to be used as a feed. Genetic modification of the source of forage is absolutely necessary to increase the availability of energy in the forage.

Recently, genetic modification through induced mutation using gamma rays irradiation has been developed in plant breeding technology. Mutation can expand plant genetic diversity to produce several sorghum mutant lines which designed for feed as brown midrib sorghum mutant lines (BMR). BMR usually has lower lignin content (Dann et al., 2008; Astigarraga et al., 2014). A structure modification in cell wall during mutation process decreases lignin content and increases cellulose content, fiber content in forage (cellulose and hemicellulose) as energy sources for livestock. The decrease in lignin content in BMR sorghum increases the efficiency of energy conversion and nutrition content (Gressel, 2008).

Forage quantity and quality are directly related with harvest times. Optimum harvest time correlates with optimum nutrition content and maximum yield. Maturity stages of forage define the quality of forage, further maturity stage will increase fiber content while crude protein content and digestibility are reduced. It indicates that the low quality of forages will influence the productivity of livestock (Beck et al., 2013). Based on those mentioned ideas, the best maturity stage of M-10 BMR sorghum mutant lines should be found. In addition, it is necessary to investigate the changes of nutrient content in stems, leaves and panicles and in-vitro dry matter and organic matter digestibilities in different generative stages of sorghum mutant lines.

\section{MATERIALS AND METHODS}

This research was arranged into a randomized block design with 2 factors. The first factor was M-10 BMR sorghum mutant lines (Patir 3.1, Patir 3.2, and Patir 3.7) and the second factor was generative stages (flowering, soft dough and hard dough phase). Data were analyzed by using analysis of variance (ANOVA) by using the SPSS 16 software program. Duncan Multiple Range Test was conducted if significant difference occurred (Steel \& Torrie, 1997).

The culture technique and sample preparation of sorghum mutant line refered to Sriagtula et al. (2016a). Seeds were sown in $20 \times 60 \mathrm{~cm}$ planting area at $5 \mathrm{~cm}$ depth. At 14 days post planting, fertilizers (urea, tri sodium phosphate, and potassium chloride) were applied in a ratio of 4:3:2 (g/g/g) at $270 \mathrm{~kg} / \mathrm{ha}$. Second fertilizer application was performed at 50 days post-planting with a ratio of 2:4:2 (g/g/g) at $200 \mathrm{~kg} / \mathrm{ha}$. Harvesting was done after the plant entered the flowering (74 days after sowing/das), soft dough (90 das) and hard dough (110 das) phases. To determine dry weight, stems, leaves and panicles were placed into individual paper bags and dried at $60^{\circ} \mathrm{C}$ for $48 \mathrm{~h}$. Samples were then grinded at $<1$ $\mathrm{mm}$ mash and prepared for nutritional analysis.

In vitro digestibility test was carried out by using Tilley \& Terry (1963) method. $0.5 \mathrm{~g}$ of each sample was weighed and incubated for $48 \mathrm{~h}$ with a mixture of $40 \mathrm{~mL}$ of McDougall buffer solution and $10 \mathrm{~mL}$ of rumen fluid with $\mathrm{CO}_{2}$. At the end of the first fermentation, microbial activity was stopped with 2-3 drops of $\mathrm{HgCl}_{2}$. This was followed by the inoculation period of $48 \mathrm{~h}$ with the addition of $50 \mathrm{~g}$ pepsin $\mathrm{HCl}$. This method was employed with rumen liquor obtained from three rumen-fistulated adult Bali cattle that were fed ad libitum with the ratio of roughage : concentrate was 60:40.

The observed parameters were crude protein (CP), crude fiber $(\mathrm{CF})$, ash, and crude fat (EE) contents in leaves, stems, and panicles. Sugar Brix was measured on sorghum stem. The in vitro dry matter digestibility (DMD) and organic matter digestibility (OMD) of the whole plant of sorghum mutant lines were also measured.

The quality of the mutant sorghum plant was measured by proximate analysis with AOAC method (1980) to obtain the crude protein, crude fiber, ash, crude fat content and Brix sugar was measured using a refractometer. Nitrogen Free Extract (NFE) was calculated from moisture, $\mathrm{CP}, \mathrm{CF}, \mathrm{EE}$, and ash with formula $\mathrm{NFE}=$ 100- (moisture + ash + crude fat + Crude protein + crude fiber) referred to Tillman et al. (1998). 


\section{RESULTS}

\section{Crude Protein, Crude Fiber, Ash, and Crude Fat Contents of M-10 Sorghum Mutant Lines}

The magnitude of CP contained in stems, leaves, and panicles at three different generative stages are shown in Table 1. The interaction between sorghum mutant lines and generative stages had significant effect $(\mathrm{P}<0.05)$ on crude protein in stems. Among of three generative stages, the highest $\mathrm{CP}$ content of all sorghum mutant lines was produced at the flowering phase i.e., $4.58 \%-5.22 \%$. At the soft dough phase, the stems CP content reduced to $2.10 \%-3.03 \%$ and continually reduced to $2.13 \%-2.31 \%$ at the hard dough phase. The leaves CP content was significantly influenced $(\mathrm{P}<0.05)$ by sorghum mutant lines. BMR sorghum mutant lines Patir 3.2 and Patir 3.7 had higher leaves CP contents compared with non-BMR sorghum mutant lines Patir 3.1 i.e., $11.61 \%, 11.07 \%$, and $10.49 \%$, respectively. The leaves $\mathrm{CP}$ content was also significantly influenced $(\mathrm{P}<0.05)$ by generative stages. The highest leaves $\mathrm{CP}$ content was produced at the flowering phase and continually reduced at the soft dough and hard dough phase i.e., $12.36 \%, 11.61 \%$, and $9.20 \%$ respectively.
Crude fiber (CF) contents of leaves, stems, and panicles of sorghum mutant which observed at three different generative stages are shown in Table 1. Crude fiber content of stems was significantly influenced by sorghum mutant lines or generative stage $(\mathrm{P}<0.01)$ but no interaction effect of both parameters. Non-BMR sorghum mutant lines (Patir 3.1) and BMR sorghum mutant lines (Patir 3.2) produced higher CF content compared with Patir 3.7 i.e., $26.33 \%, 25.40 \%$, and $22.33 \%$, respectively. In leaves, sorghum mutant lines or generative stage had no significant effect on CF content as well as the interaction between both parameters. The crude fiber content in stems ranged between $23.20 \%-25.95 \%$. Meanwhile, the interaction between sorghum mutant lines and harvest times influenced the content of leaves $\mathrm{CF}(\mathrm{P}<0.05)$. In all sorghum mutant lines, the highest $\mathrm{CF}$ content was produced during the flowering phase and decrease during the soft dough phase. The lowest content was produced during the hard dough phase.

Ash contents in stems, leaves, and panicles are presented in Table 2. The result showed that an interaction between sorghum mutant lines and generative stages influenced the stems ash content $(\mathrm{P}<0.05)$. The highest ash content was produced during hard dough phase $(7.86 \%)$ by non-BMR sorghum mutant lines (Patir 3.1) and the

Table 1. Crude protein and crude fibre contents of M-10 sorghum mutant lines (based on $100 \%$ dry matter)

\begin{tabular}{|c|c|c|c|c|c|}
\hline \multirow{2}{*}{ Plant organ } & \multirow{2}{*}{ Generative phase } & \multicolumn{3}{|c|}{ Sorghum mutant lines } & \multirow{2}{*}{ Mean } \\
\hline & & Patir 3.1 & Patir 3.2 & Patir 3.7 & \\
\hline \multicolumn{6}{|l|}{ Crude protein } \\
\hline \multirow[t]{4}{*}{ Stem } & Flowering & $5.21 \pm 0.00^{\mathrm{a}}$ & $5.22 \pm 0.52^{\mathrm{a}}$ & $4.58 \pm 0.46^{\mathrm{b}}$ & $5.00 \pm 0.33$ \\
\hline & Soft dough & $2.81 \pm 0.6^{\mathrm{cd}}$ & $3.03 \pm 0.78^{c}$ & $2.10 \pm 0.32^{\mathrm{e}}$ & $2.64 \pm 0.59$ \\
\hline & Hard dough & $2.15 \pm 0.33^{e}$ & $2.13 \pm 0.07 \mathrm{e}$ & $2.31 \pm 0.22^{\mathrm{de}}$ & $2.19 \pm 0.21$ \\
\hline & Mean & $3.39 \pm 0.34$ & $3.46 \pm 0.45$ & $2.99 \pm 0.34$ & \\
\hline \multirow[t]{4}{*}{ Leave } & Flowering & $11.65 \pm 0.85$ & $13.07 \pm 0.94$ & $12.36 \pm 0.61$ & $12.36 \pm 0.80^{\mathrm{A}}$ \\
\hline & Soft dough & $10.96 \pm 1.03$ & $12.36 \pm 0.69$ & $11.50 \pm 0.43$ & $11.61 \pm 0.72^{\mathrm{B}}$ \\
\hline & Hard dough & $8.88 \pm 0.39$ & $9.39 \pm 0.83$ & $9.33 \pm 0.41$ & $9.20 \pm 0.54^{\mathrm{C}}$ \\
\hline & Mean & $10.49 \pm 0.76^{\mathrm{b}}$ & $11.61 \pm 0.82^{\mathrm{a}}$ & $11.07 \pm 0.48^{\mathrm{ab}}$ & \\
\hline \multirow[t]{4}{*}{ Panicle } & Flowering & $9.33 \pm 0.29^{c}$ & $8.94 \pm 0.49^{\mathrm{C}}$ & $8.51 \pm 0.43^{\text {В }}$ & $8.93 \pm 0.40$ \\
\hline & Soft dough & $10.19 \pm 0.29^{\mathrm{B}}$ & $10.79 \pm 0.34^{\mathrm{AB}}$ & $10.92 \pm 0.69^{\mathrm{AB}}$ & $10.63 \pm 0.44$ \\
\hline & Hard dough & $8.92 \pm 0.47 c$ & $10.80 \pm 0.26^{\mathrm{AB}}$ & $11.06 \pm 0.63^{\mathrm{A}}$ & $10.26 \pm 0.46$ \\
\hline & Mean & $9.48 \pm 0.35$ & $10.18 \pm 0.37$ & $10.17 \pm 0.58$ & \\
\hline \multicolumn{6}{|l|}{ Crude fiber } \\
\hline \multirow[t]{4}{*}{ Stem } & Flowering & $27.97 \pm 1.79$ & $28.13 \pm 1.68$ & $25.57 \pm 1.78$ & $27.22 \pm 1.75^{\mathrm{A}}$ \\
\hline & Soft dough & $22.95 \pm 1.43$ & $23.00 \pm 0.86$ & $20.02 \pm 1.14$ & $21.99 \pm 1.14^{\mathrm{C}}$ \\
\hline & Hard dough & $28.08 \pm 1.72$ & $25.08 \pm 2.52$ & $21.38 \pm 1.61$ & $24.85 \pm 1.95^{\mathrm{B}}$ \\
\hline & Mean & $26.33 \pm 1.65^{\mathrm{A}}$ & $25.40 \pm 1.69^{\mathrm{A}}$ & $22.33 \pm 1.51^{\mathrm{B}}$ & \\
\hline \multirow[t]{4}{*}{ Leave } & Flowering & $24.40 \pm 0.79$ & $25.95 \pm 2.75$ & $25.77 \pm 3.08$ & $25.37 \pm 2.20$ \\
\hline & Soft dough & $23.20 \pm 0.35$ & $24.91 \pm 1.79$ & $23.90 \pm 1.45$ & $24.00 \pm 1.20$ \\
\hline & Hard dough & $25.53 \pm 1.00$ & $25.38 \pm 1.70$ & $25.33 \pm 0.66$ & $25.41 \pm 1.12$ \\
\hline & Mean & $24.38 \pm 0.71$ & $25.41 \pm 2.08$ & $25.00 \pm 1.73$ & \\
\hline \multirow[t]{4}{*}{ Panicle } & Flowering & $25.63 \pm 1.26^{\mathrm{b}}$ & $29.97 \pm 1.91^{\mathrm{a}}$ & $29.95 \pm 2.30^{\mathrm{a}}$ & $28.52 \pm 1.82$ \\
\hline & Soft dough & $11.87 \pm 1.25^{\mathrm{d}}$ & $14.75 \pm 1.72^{c}$ & $10.70 \pm 1.70^{\mathrm{de}}$ & $12.44 \pm 1.56$ \\
\hline & Hard dough & $6.85 \pm 0.79^{f}$ & $8.87 \pm 2.23^{\text {ef }}$ & $7.61 \pm 1.26^{\mathrm{f}}$ & $7.78 \pm 1.43$ \\
\hline & Mean & $14.78 \pm 1.10$ & $17.86 \pm 1.96$ & $16.09 \pm 1.75$ & \\
\hline
\end{tabular}

Note: Means with different superscripts in uppercase and lowercase differ significantly at $\mathrm{P}<0.01$ and $\mathrm{P}<0.05$, respectively. Patir $3.1=$ non-BMR sorghum mutant line; Patir 3.2-Patir 3.7= BMR sorghum mutant lines. 
lowest ash content was produced during soft dough phase $(4.67 \%)$ by BMR sorghum mutant lines (Patir 3.2). Sorghum mutant lines or generative stage had no significant effect on ash content in leaves. The ash content in panicles was influenced by generative stage $(\mathrm{P}<0.01)$ and it decreased with the increased generative stage.

The crude fat (EE) contents in stems, leaves, and panicles are shown in Table 2. The result showed that EE in stems was influenced by generative stage $(\mathrm{P}<0.05)$. The EE content in stems during hard dough phase was higher than flowering and hard dough phase i.e., $1.30 \%, 0.94 \%$, and $0.92 \%$ respectively. The EE in panicles was also significantly influenced by generative stage $(\mathrm{P}<0.01)$. The hard dough and soft dough phase produced the higher EE content $(2.10 \%$ and $1.74 \%)$ compared to flowering phase $(0.94 \%)$.

\section{Brix Sugar of Stems of M-10 Sorghum Mutant Lines}

The stem sugar in the study is present in Table 3. Studies have shown that sorghum stem sugar was affected by the interaction between sorghum mutant lines and maturity stages $(\mathrm{P}<0.01)$. BMR sorghum mutant lines produce higher stem sugar content (13.37\%$13.93 \%$ Brix) compared to non-BMR sorghum mutant line $(11.58 \%$ Brix). Sugar content in the sorghum stem increased with the increased maturity stage (hard dough stage) in this study. Stem sugar contents from flowering, soft dough, and hard dough phase were $12.01 \%, 13.68 \%$, and $14.81 \%$ Brix, respectively.

\section{In Vitro Digestibilities of Dry Matter and Organic Material of M-10 Sorghum Mutant Lines}

The DMD and OMD are presented in Table 4. There is no interaction between sorghum mutant lines

Table 3. The mean of stems sugar contents of sorghum mutant lines (\% brix)

\begin{tabular}{ccccc}
\hline Sorghum & \multicolumn{3}{c}{ Generative stage } & \multirow{2}{*}{ Mean } \\
\cline { 2 - 4 } $\begin{array}{c}\text { mutant } \\
\text { lines }\end{array}$ & Flowering & Soft dough & Hard dough & \\
\hline Patir 3.1 & $10.67 \pm 0.72^{\mathrm{C}}$ & $12.37 \pm 0.49^{\mathrm{B}}$ & $11.63 \pm 2.30^{\mathrm{BC}}$ & $11.56 \pm 0.86^{\mathrm{B}}$ \\
Patir 3.2 & $11.28 \pm 0.60^{\mathrm{BC}}$ & $14.77 \pm 0.42^{\mathrm{A}}$ & $15.80 \pm 0.61^{\mathrm{A}}$ & $13.95 \pm 0.54^{\mathrm{A}}$ \\
Patir 3.7 & $12.27 \pm 1.17^{\mathrm{BC}}$ & $12.60 \pm 0.10^{\mathrm{B}}$ & $15.23 \pm 1.44^{\mathrm{A}}$ & $13.37 \pm 0.90^{\mathrm{A}}$ \\
Mean & $11.41 \pm 0.83^{\mathrm{C}}$ & $13.24 \pm 0.38^{\mathrm{B}}$ & $14.22 \pm 1.14^{\mathrm{A}}$ & \\
\hline
\end{tabular}

Note: Means with different superscripts in uppercase differ significantly $(\mathrm{P}<0.01)$. Patir 3.1= non-BMR sorghum mutant line; Patir 3.2-Patir 3.7= BMR sorghum mutant lines.

Table 2. Ash dan crude fat contents of sorghum mutant lines (based on 100\% dry matter)

\begin{tabular}{|c|c|c|c|c|c|}
\hline \multirow{2}{*}{ Plant organ } & \multirow{2}{*}{ Generative phase } & \multicolumn{3}{|c|}{ Sorghum mutant lines } & \multirow{2}{*}{ Mean } \\
\hline & & Patir 3.1 & Patir 3.2 & Patir 3.7 & \\
\hline \multicolumn{6}{|l|}{ Ash } \\
\hline \multirow[t]{4}{*}{ Stem } & Flowering & $5.49 \pm 0.17^{\mathrm{bc}}$ & $6.31 \pm 1.13^{\mathrm{b}}$ & $5.29 \pm 0.61^{\mathrm{bc}}$ & $5.69 \pm 0.64$ \\
\hline & Soft dough & $5.44 \pm 0.56^{\mathrm{bc}}$ & $4.67 \pm 0.87 \mathrm{c}$ & $4.98 \pm 0.04^{\mathrm{bc}}$ & $5.03 \pm 0.49$ \\
\hline & Hard dough & $7.86 \pm 0.05^{\mathrm{a}}$ & $4.87 \pm 1.18^{\mathrm{bc}}$ & $5.48 \pm 0.39^{b c}$ & $6.07 \pm 0.54$ \\
\hline & Mean & $6.27 \pm 0.26$ & $5.28 \pm 1.06$ & $5.25 \pm 0.34$ & \\
\hline \multirow[t]{4}{*}{ Leave } & Flowering & $10.72 \pm 0.58$ & $11.12 \pm 0.79$ & $11.31 \pm 0.28$ & $11.05 \pm 0.55$ \\
\hline & Soft dough & $11.01 \pm 0.43$ & $11.04 \pm 0.56$ & $12.26 \pm 0.47$ & $11.44 \pm 0.49$ \\
\hline & Hard dough & $13.24 \pm 0.25$ & $12.03 \pm 0.45$ & $12.50 \pm 1.29$ & $12.59 \pm 0.66$ \\
\hline & Mean & $11.65 \pm 0.42$ & $11.39 \pm 0.60$ & $12.03 \pm 0.68$ & \\
\hline \multirow[t]{4}{*}{ Panicle } & Flowering & $5.16 \pm 0.13$ & $4.97 \pm 0.13$ & $4.75 \pm 0.18$ & $4.96 \pm 0.15^{\mathrm{A}}$ \\
\hline & Soft dough & $4.44 \pm 0.21$ & $4.41 \pm 0.41$ & $4.43 \pm 0.25$ & $4.43 \pm 0.29^{\mathrm{B}}$ \\
\hline & Hard dough & $3.62 \pm 0.30$ & $3.79 \pm 0.34$ & $3.28 \pm 0.25$ & $3.56 \pm 0.30^{C}$ \\
\hline & Mean & $4.41 \pm 0.21$ & $4.39 \pm 0.30$ & $4.15 \pm 0.22$ & \\
\hline \multicolumn{6}{|l|}{ Crude fat } \\
\hline \multirow[t]{4}{*}{ Stem } & Flowering & $1.16 \pm 0.34$ & $0.70 \pm 0.23$ & $0.96 \pm 0.32$ & $0.94 \pm 0.29 b$ \\
\hline & Soft dough & $0.85 \pm 0.14$ & $0.98 \pm 0.70$ & $0.93 \pm 0.14$ & $0.92 \pm 0.33^{b}$ \\
\hline & Hard dough & $1.19 \pm 0.47$ & $1.22 \pm 0.10$ & $1.48 \pm 0.08$ & $1.30 \pm 0.22^{\mathrm{a}}$ \\
\hline & Mean & $1.07 \pm 0.31$ & $0.97 \pm 0.34$ & $1.12 \pm 0.18$ & \\
\hline \multirow[t]{4}{*}{ Leave } & Flowering & $2.21 \pm 0.57$ & $1.93 \pm 0.66$ & $1.94 \pm 0.58$ & $2.02 \pm 0.61$ \\
\hline & Soft dough & $1.98 \pm 0.43$ & $2.03 \pm 0.88$ & $2.31 \pm 0.47$ & $2.10 \pm 0.60$ \\
\hline & Hard dough & $2.43 \pm 0.34$ & $1.99 \pm 0.46$ & $2.30 \pm 0.16$ & $2.24 \pm 0.32$ \\
\hline & Mean & $2.20 \pm 0.45$ & $1.98 \pm 0.67$ & $2.18 \pm 0.40$ & \\
\hline \multirow[t]{4}{*}{ Panicle } & Flowering & $1.02 \pm 0.28$ & $0.89 \pm 0.04$ & $0.89 \pm 0.26$ & $0.94 \pm 0.19^{\mathrm{B}}$ \\
\hline & Soft dough & $1.24 \pm 0.08$ & $2.09 \pm 0.80$ & $1.91 \pm 0.35$ & $1.74 \pm 0.41^{\mathrm{A}}$ \\
\hline & Hard dough & $1.95 \pm 0.25$ & $1.91 \pm 0.38$ & $2.45 \pm 0.14$ & $2.10 \pm 0.26^{\mathrm{A}}$ \\
\hline & Mean & $1.40 \pm 0.20$ & $1.63 \pm 0.41$ & $1.75 \pm 0.25$ & \\
\hline
\end{tabular}

Note: Means with different superscripts in uppercase and lowercase differ significantly at $\mathrm{P}<0.01$ and $\mathrm{P}<0.05$, respectively. Patir $3.1=$ non-BMR sorghum mutant line; Patir 3.2-Patir 3.7= BMR sorghum mutant lines. 
Table 4. In vitro dry matter and organic matter digestibilities of sorghum mutant lines (\%)

\begin{tabular}{|c|c|c|c|c|c|}
\hline \multirow{2}{*}{ Parameters } & \multirow{2}{*}{$\begin{array}{c}\text { Generative } \\
\text { phase }\end{array}$} & \multicolumn{3}{|c|}{ Sorghum mutant lines } & \multirow{2}{*}{ Mean } \\
\hline & & Patir 3.1 & Patir 3.2 & Patir 3.7 & \\
\hline \multirow[t]{4}{*}{ DMD } & Flowering & $50.90 \pm 1.27$ & $57.28 \pm 1.62$ & $54.51 \pm 0.30$ & $54.23 \pm 1.06^{\mathrm{C}}$ \\
\hline & Soft dough & $62.93 \pm 1.60$ & $68.82 \pm 1.01$ & $67.64 \pm 1.09$ & $66.47 \pm 1.23^{\text {В }}$ \\
\hline & Hard dough & $66.46 \pm 1.26$ & $71.55 \pm 1.53$ & $68.21 \pm 0.57$ & $68.74 \pm 1.12^{\mathrm{A}}$ \\
\hline & Mean & $60.10 \pm 1.37^{C}$ & $65.88 \pm 1.39^{\mathrm{A}}$ & $63.45 \pm 0.65^{\text {B }}$ & \\
\hline \multirow[t]{4}{*}{ OMD } & Flowering & $50.63 \pm 1.45$ & $57.05 \pm 1.75$ & $54.21 \pm 0.42$ & $53.96 \pm 1.21^{\mathrm{C}}$ \\
\hline & Soft dough & $63.62 \pm 1.18$ & $69.77 \pm 1.46$ & $68.53 \pm 0.95$ & $67.31 \pm 1.19^{\mathrm{B}}$ \\
\hline & Hard dough & $67.52 \pm 1.29$ & $72.97 \pm 1.43$ & $69.42 \pm 0.12$ & $70.03 \pm 0.95^{\mathrm{A}}$ \\
\hline & Mean & $60.59 \pm 1.30^{c}$ & $66.59 \pm 1.55^{\mathrm{A}}$ & $63.38 \pm 0.50^{\mathrm{B}}$ & \\
\hline
\end{tabular}

Note: Means with different superscripts in uppercase differ significantly $(\mathrm{P}<0.01)$. Patir 3.1= non-BMR sorghum mutant line; Patir 3.2-Patir 3.7= BMR sorghum mutant lines; $\mathrm{DMD}=$ dry matter digestibility, $\mathrm{OMD}=$ organic matter digestibility

and generative stage on dry matter digestibility (DMD). However, DMD was influenced by sorghum mutant lines $(\mathrm{P}<0.01)$. The highest digestibility $(65.88 \%)$ was found in BMR sorghum mutant lines (Patir 3.2) and the lowest digestibility $(60.10 \%)$ was found in non-BMR (Patir 3.1). Dry matter digestibility was also influenced by generative stage $(\mathrm{P}<0.01)$. The highest dry matter digestibility was obtained at hard dough phase $(68.74 \%)$ and the lowest was obtained at flowering phase $(54.23 \%)$.

Organic matter digestibility was influenced by sorghum mutant lines $(\mathrm{P}<0.01)$. The highest organic matter digestibility $(66.59 \%)$ was produced by BMR sorghum mutant lines (Patir 3.2) while the lowest organic matter digestibility $(60.59 \%)$ was produced by non-BMR (Patir 3.1). The OMD was also influenced by generative stage $(\mathrm{P}<0.01)$. The highest OMD was obtained at hard dough phase $(70.037 \%)$ and the lowest was obtained at flowering phase $(53.69 \%)$.

\section{DISCUSSION}

The declining trend of stems and leaves CP contents during further generative stage (soft dough and hard dough phase) could be related to the inhibition of protein synthesis in the aging plant (Baloyi et al., 2013). In contrast to the stems and leaves, panicles experienced an increasing trend of CP. This trend can be due to the movement of nutrient content from stems and leaves to grain which associates with the increased maturity of the plant (Atis et al., 2012; Fernandes et al., 2014). In this research it was found that $\mathrm{CP}$ content at BMR sorghum mutant lines was higher than non-BMR sorghum mutant line. This result is in agreement with the report of de Aquilar et al. (2014) who also stated that CP content of BMR lines was $0.6 \%$ higher than non-BMR which harvested at soft dough stage.

In this study, the stems CF content was decrease with the increased generative stage, because of Sorghum bicolor is sweet sorghum that has two sinks: stems and grains. Low CF content in stems is due to the less portion of structural carbohydrate as sugar accumulates in stems and for grain development. Grain filling occurs at the soft dough and hard dough phase, therefore, carbohydrate proportion will be trans-located from stems to panicles and at the same time sugar accumulates in the stems (Carmi et al., 2006; Qu et al., 2014). Low CF content in panicles at the further generative stage is due to the increasing content of starch in grains. This is in agreement with the findings of Marsalis et al. (2009) who stated that the increased non-fiber carbohydrate and decreased fiber fractions during the increased generative stage are due to the increased starch content in grains. In this study, it was found that the CF deacreased in stem and panicle at soft dough and hard dough phases while the stem sugar were higher at the same phases (Table 1 and Table 3).

Ash content represents mineral content. There is no different in ash contents of leaves related to the mobile characteristic of nutrient at leaves which will be translocated to other parts of the plant to fill the grain (Atis et al., 2012; Fernandes et al., 2014). The ash content in this study was decreased with the increased generative stage. The same trends were also found by Koten et al. (2014) that sorghum harvested at the stage of initiation of grain development had higher ash content compared with those harvested at further maturity (soft dough phase). This result was due to the increased starch content of grains during further generative stage (Marsalis et al., 2009) and the increased organic content such as starch in grain and sugar in the stem as an accumulation result of photosynthesis so that the inorganic matter (ash) was measured lower (Rosser, 2013).

Sorghum leaves have high EE content due to the presence of a wax coating on leaves surfaces. This coating material may prevent water loss during transpiration. Wax material is insoluble in ether leading to a higher crude fat contained in forage material (Buschhaus \& Jetter, 2012). The general result showed that EE increased with the increased generative stage. The hard dough and soft dough phases result in a higher crude fat contents of panicles than others, due to the high starch content in this phase. In seeds, lipids are positively correlated with starch and is an integral part of starch in the form of lysophospholipid (LPL) and free fatty Acids (FFA) as a starch-lipid complex (Tang \& Copeland, 2007). Sorghum leaves have abusive fat content which is quite large because of the wax coating on the leaf surface. Layers of wax in plants inhibit water loss due to transpiration. The wax is soluble in ether and 
included into the ether extract so that the crude fat value in forage fodder has a higher value (Tillman et al., 1998). The EE content in leaves found in this research was $1.98 \%-2.20 \%$, that was lower than the result reported by Koten et al. (2014) i.e., 3.99\%-6.96\%.

In general, sugar levels in the sorghum stem increased with the increased maturity stage (hard dough phase) that was a seed maturation period. The sugar content of sorghum stem was influenced by stem maturity of sorghum. Increase in stems maturity will increase sugar content. The maturity of the sorghum stem due to the maximum sugar content is achieved at physiological maturity of sorghum seed. This result is in accordance with the results reported by Almodares et al. (2007) that the highest sugar content of sorghum stem was found when the plant enters the physiological maturity of seed at 120 das. A similar statement was also expressed by Long et al. (2006) that the sugar contents of two sweet sorghum varieties were lower at early flowering phase then gradually increased from the milky phase to seed maturation. The low sugar content in the flowering phase was caused by the translocation of photosynthesis materials into the seeds, and a part of the sugar in sorghum stem was used as energy to support plant physiological process (Sucipto, 2010). Low lignin content in BMR mutant lines is caused by the sugar content of the stem was higher than a non-BMR mutant line (Scully et al., 2016).

The DMD is in line with the OMD. At this study, the highest in vitro digestibility was found at BMR sorghum mutant lines (Patir 3.2 and Patir 3.7) compared with non-BMR sorghum mutant lines (Patir 3.1). This finding corresponds to Puteri et al. (2015) that in vitro DMD and OMD of sorghum mutant lines (Patir 3.5, Patir 3.6, and Patir 3.7) were higher than Samurai (M-17) (non-BMR sorghum mutant line). The increased digestibility was caused by the gene mutation in BMR which reduces lignin content (Ledgerwood, 2009; Tesso \& Ejeta, 2011; Rao et al. 2012; Sattler, 2014). Our previous research (Sriagtula et al., 2016a) reported the decrease in stem lignin in Patir 3.2 and Patir 3.7 BMR sorghum mutant lines that were $3.03 \%$ and $3.28 \%$. Based on generative stage, the higher in vitro digestibility was obtained during hard dough compared to during the soft dough and flowering. This result is due to the decreased content of crude fiber, and the increased content of sugar in stem and NFE in sorghum at further maturity (Table 3 and Figure 1). Crude fiber was reflected as ADF, NDF, and lignin. Refer to Carmi et al. (2006); Sriagtula et al. (2016a) that decreasing of ADF, NDF, and lignin during hard dough stage and increasing the content of sugar in stems and grain proportion eventually affected in vitro digestibility. Refer to Sriagtula et al. (2016b) the highest panicle proportion produced by all sorghum mutant lines was at the hard dough phase. Qu et al. (2014) stated that the decrease in plant fiber content at soft dough phase would increase in vitro DMD. However, Rosser et al. (2013) stated that further maturity of forage crops did not reduce in vitro OMD.

In this research, in vitro DMD at the flowering phase was $54.23 \%$ and at soft dough phase was $66.47 \%$. Those values were slightly different from the result

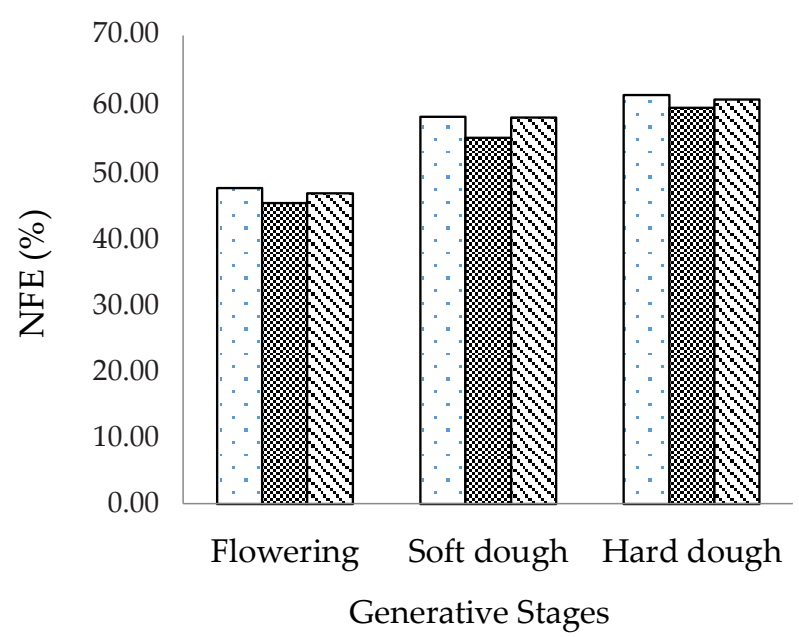

Figure 1. Nitrogen Free Extract of sorghum mutant lines, Patir 3.1 ( $\square)$, Patir 3.2 (凅), Patir 3.7 (囚).

found by Carmi et al. (2006) who stated that the ranges of in vitro DMD of sorghum at flowering phase was $61 \%-70 \%$ and soft dough phase was $61 \%-65 \%$.

\section{CONCLUSION}

BMR sorghum mutant lines produced higher $\mathrm{CP}$ and lower CF compared with non-BMR sorghum mutant lines (Patir 3.1). The increasing generative stage decreased $\mathrm{CP}, \mathrm{CF}$, and ash contents meanwhile increased EE. BMR sorghum mutant lines produced higher digestibility compared to non-BMR sorghum mutant lines. The maturity stage at hard dough stage increased in vitro digestibility. The highest in-vitro DMD and OMD were produced at Patir 3.2 and hard dough phase.

\section{ACKNOWLEDGEMENT}

We would like to express our gratitude to Ministry of Research, Technology and Higher Education of Indonesia for financial support through competitive grants (Doctoral Grant-Programs), Project ID No: 01/H.16/DD/LPPM/2016.

\section{REFERENCES}

Abdelhadi L. O, \& J. M. Tricarico. 2009. Effects of stage of maturity and microbial inoculation at harvest on nutritive quality and degradability of grain sorghum whole-plant and head-chop silages. Anim. Feed Sci. Tech. 152:175-185. https://doi.org/10.1016/j.anifeedsci.2009.04.014

Almodares, A., M.R. Hadi., M. Ranjbar, \& R. Taheri. 2007. The effects of nitrogen treatments, cultivars and harvest stages on stlak yield and sugar content in sweet sorghum. Asian J. Plant Sci. 6: 423-426. https://doi.org/10.3923/ ajps.2007.423.426

AOAC. 1980. Official Methods of Analysis. $13^{\text {th }}$ Edition. Association of Official Analytical Chemist, Washington DC.

Astigarraga, L., A. Bianco., R. Mello, \& D. Montedónico. 2014. Comparison of brown midrib sorghum with conventional sorghum forage for grazing dairy cows. Am. J. Plant Sci. 5: 955-962. https://doi.org/10.4236/ajps.2014.57108 
Atis, I., O. Konuskan., M. Duru., H. Gozubenli, \& S. Yilmaz. 2012. Effect of harvesting time on yield, composition and forage quality of some forage sorghum cultivars. Int. J. Agric. Biol. 14: 879-886.

Baloyi, B.M., V. I. Ayodele, \& A. Addo-Bediako. 2013. Effects of leaf harvest on crude protein and mineral contents of selected early maturing lines of lablab (Lablab purpureus). Afr. J. Agric. Res.Vol. 8: 449-453.

Beck, P., K. Poe., B. Stewart, P. Capps, \& H. Gray. 2013. Effect of brown midrib gene and maturity at harvest on forage yield and nutritive quality of sudangrass. Grassland Science 59: 52-58. https://doi.org/10.1111/grs.12007

Buschhaus, C., \& R. Jetter. 2012. Composition and physiological function of the wax layers coating arabidopsis leaves: b-Amyrin negatively affects the intracuticular water barrier. Plant Physiol. 160: 449-453. https://doi.org/10.1104/ pp.112.198473

Carmi, A., Y. Aharoni, M. Edelstein, N. Umiel., A. Hagiladi, E. Yosef, M. Nikbachat, A. Zenou, \& J. Miron. 2006. Effects of irrigation and plant density on yield, composition and in vitro digestibility of a new forage sorghum variety, Tal, at two maturity stages. Anim. Feed Sci. Technol. 131: 120 132. https://doi.org/10.1016/j.anifeedsci.2006.02.005

Dann, H.M., R. J. Grant, K. W. Cotanch, E. D. Thomas, C. S. Ballard, \& R. Rice. 2008. Comparison of brown midrib sorghum-sudangrass with corn silage on lactational performance and nutrient digestibility in Holstein Dairy Cows. J. Dairy Sci. 91:663-672. https://doi.org/10.3168/jds.2007-0521

Dahir, M., K. X. Zhu., X. N. Guo., W. Aboshora, \& W. Peng. 2015. Possibility to Utilize Sorghum Flour in a Modern Bread Making Industry. JAIR 4:128-135.

de Aguilar, P.B., D. A de Assis Pires, B. C. B. Frota, J. A. S. Rodrigues, S. T dos Reis, \& V. R. R. Júnior. 2014. Nutritional characteristics of BMR mutant and normal sorghum genotypes used for cutting and grazing. Acta Scientiarum, Anim. Sci. Maringá 36:259-264. https://doi. org/10.4025/actascianimsci.v36i3.21284

Fernandes, G., T. G. Braga, J. Fischer, R. A. C. Parrella., M. M. de Resende, \& V. L. Cardoso. 2014. Evaluation of potential ethanol production and nutrients for four varieties of sweet sorghum during maturation. Renewable Energy 71: 518-524. https://doi.org/10.1016/j.renene.2014.05.033

Gressel, J. 2008. Transgenics are imperative for biofuel crops (Review). Plant Sci. 174: 246 -263. https://doi.org/10.1016/j. plantsci.2007.11.009

Koten, B. B., R. D. Soetrisno., N. Ngadiyono, \& B Soewignyo. 2014. Perubahan nilai nutrient tanaman sorgum (Sorghum bicolor (L.) Moench) varietas lokal rote sebagai hijauan pakan ruminansia pada berbagai umur panen dan dosis pupuk urea. Pastura 3: $55-60$.

Ledgerwood, D. N., E. J. DePeters., P. H. Robinson., S. J. Taylor, \& J. M. Heguy. 2009. Assessment of a brown midrib (BMR) mutant gene on the nutritive value of sudangrass using in vitro and in vivo techniques. Anim. Feed Sci. Tech. 150:207222. https://doi.org/10.1016/j.anifeedsci.2008.10.001

Long, B. Y., Y. Seiji, I. Maiko, \& C. H. Wei. 2006. QTLs for sugar content of stalk in sweet sorghum (Sorghum bicolor L. Moench). Agricultural Sciences in China 5: 736-744. https:// doi.org/10.1016/S1671-2927(06)60118-1

Marsalis, M. A., S. Angadi., F. E. Contreras-Govea, \& R. E. Kirksey. 2009. Harvest timing and by product addition effects on corn and forage Sorghum silage grown under water stress. Bull. 799. NMSU Agric. Exp. Stn., Las Cruces, NM.
Puteri, R.E., P. D. M. H. Karti., L. Abdullah, \& Supriyanto. 2015. Productivity and nutrient quality of some sorghum mutant lines at different cutting ages. Med Pet. 38:132-137. https://doi.org/10.5398/medpet.2015.38.2.132

Qu, H., X. Bao Liu., C.F Dong., X. Y Lu, \& Y. X. Shen. 2014 Field performance and nutritive value of sweet sorghum in eastern China. Field Crops Res. 157: 84-88. https://doi. org/10.1016/j.fcr.2013.12.010

Rao, P. S., S. Deshpande., M. Blümmel., B. V. S. Reddy, \& T. Hash. 2012. Characterization of Brown Midrib Mutants of Sorghum (Sorghum bicolor (L.) Moench). The European J. Plant Sci. Biotech. 6:71-75.

Rosser, C. L., P. Gorka., A. D. Beattie., H. C. Block., J. J. Mckinnon., H. A. Lardner, \& G. B. Penner. 2013. Effect of maturity at harvest on yield, chemical composition, and in situ degradability for annual cereals used for swath grazing. J. Anim. Sci. 91:3815-3826. https://doi.org/10.2527/ jas.2012-5677

Sari, M., A.Ferret, \& S. Calsamiglia. 2015. Effect of pH on in vitro microbial fermentation and nutrient flow indiets containing barley straw or non-forage fiber sources. Anim. Feed Sci. Tech. 200:17-24. https://doi.org/10.1016/j. anifeedsci.2014.11.011

Sattler, SE., A. Saballos, Z. Xin, D. L. F. Harris, W. Vermerris, \& J. F. Pedersen. 2014. Characterization of novel sorghum brown midrib mutants from an EMS-mutagenized population. G3 (Bethesda) 4: 2115-2124. https://doi.org/10.1534/ g3.114.014001

Scully, E.D., T. Gries, D. L. Funnell-Harris, Z. Xin, F. A. Kovacs, W. Vermerris, \& S.E. Sattler. 2016. Characterization of novel Brown midrib 6 mutations affecting lignin biosynthesis in sorghum. J. Integr. Plant Biol. 58:136-49. https:// doi.org/10.1111/jipb.12375

Steel, R. G. D., \& J. H. Torri. 1997. Prinsip dan Prosedur Statistika: Suatu Pendekatan Biometrik. Edisi II. Terjemahan: B. Sumantri. PT. gramedia Pustaka Utama Jakarta.

Sriagtula, R., P. D. M. H. Karti, L. Abdullah, Supriyanto, \& D. A. Astuti. 2016a. Dynamics of fiber fraction in generative stage of M10-BMR sorghum mutant lines. IJSBAR 25: 58-69.

Sriagtula, R., P. D. M. H. Karti, L. Abdullah, Supriyanto, \& D. A. Astuti. 2016b. Growth, biomass and nutrient production of brown midrib sorghum mutant lines at different harvest times. Pak. J. Nutr. 15: 524-531. https://doi. org/10.3923/pjn.2016.524.531

Sucipto. 2010. Efektivitas cara pemupukan terhadap pertumbuhan dan hasil beberapa varietas sorgum manis (Sorghum bicolor L.Moench). Embryo 7:67-74.

Tang, M. C. \& L. Copeland. 2007. Analysis of complexes between lipids and wheat starch. Carbohydr. Polym. 67:8085. https://doi.org/10.1016/j.carbpol.2006.04.016

Tesso, T., \& G. Ejeta. 2011. Stalk strength and reaction to infection by Macrophomina phaseolina of brown midrib maize (Zea mays) and sorghum (Sorghum bicolor). Field Crops Res. 120:271-275. https://doi.org/10.1016/j.fcr.2010.10.015

Tilley, J. M. A. \& R. A. Terry. 1963. A two stage technique for the in vitro digestion of forage crop. Grass Forage Sci. 18: 104-111. https://doi.org/10.1111/j.1365-2494.1963.tb00335.x

Tillman, A. D., H. Hartadi., S. Prawirokusumo, \& Lebdosoekodjo. 1998. Ilmu Makanan Ternak Dasar. Cetakan V. Gadjah Mada University Press, Yogyakarta. 